\title{
MODEL PERTUMBUHAN DAN PRODUKSI JAGUNG HIBRIDA PADA PERLAKUAN PEMBERIAN NITROGEN SERTA PEMANGKASAN TASSEL
}

\section{GROWTH AND PRODUCTION MODEL OF HIBRYD MAIZE IN EACH TREATMENTS OF NITROGEN APPLICATION ANDTASSEL TRIMMING}

\author{
Frangky J. Paat; J.E.X. Rogi dan D.S. Runtunuwu \\ Jurusan Budidaya Pertanian, Fakultas Pertanian Universitas Sam Ratulangi Manado_ 95115 \\ E-mail : frangky.paat@yahoo.com
}

\begin{abstract}
This research was aimed to identify the growth and production model of hybrid maize in each treatments of nitrogen application and tassel trimming. This research was carried out in field experiment in Tountimomor Village of Kakas District in Minahasa Regency. The result of this research showed that this model could stimulate the growth and production of maize with the total biomass of $8000 \mathrm{~kg} / \mathrm{ha}$. Optimum leaf nitrogen of $1.6 \%$ at 49 day after cultivate. The highest leaf biomass from field measurement was reached in nitrogen fertilizing of $92 \mathrm{~kg} / \mathrm{ha}$. The highest tassel biomass from field measurement was obtained in treatment trimming which was $4 \mathrm{gr} / \mathrm{ha}$.
\end{abstract}

Keywords : Growth Model, Production, Maize, Nitrogen, Tassel Trimming

\begin{abstract}
ABSTRAK
Penelitian ini bertujuan untuk mengidentifikasi pertumbuhan dan model produksi dari jagung hibrida dalam tiap-tiap perlakuan pemberian nitrogen dan pemangkasan tassel. Penelitian ini dilaksanakan di kebun percobaan di desa Tountimomor Kecamatan Kakas Kabupaten Minahasa. Hasil dari penelitian ini menunjukan bahwa model dapat menstimulasi pertumbuhan dan produksi jagung dengan jumlah biomassa $8000 \mathrm{~kg} / \mathrm{ha}$. Nitrogen daun optimum adalah $1,6 \%$ pada 49 hari setelah ditanam. Biomassa daun tertinggi didapat pada pemberian Nitrogen sebesar $92 \mathrm{~kg} / \mathrm{ha}$. Biomassa tassel tertinggi dari pengukuran lapangan didapat dalam perlakuan pemangkasa tassel sebanyak $4 \mathrm{gr} / \mathrm{ha}$.

Kata kunci: Model pertumbuhan, Produksi, Jagung, Nitrogen, Pemangkasan Tassel.
\end{abstract}




\section{PENDAHULUAN}

Jagung merupakan palawija penting baik untuk pangan maupun pakan. Sekitar $51,4 \%$ bahan pakan menggunakan jagung dan sekitar 55 buah industri pakan dengan kapasitas produksi terpasang 11,1 juta ton membutuhkan jagung sekitar 5,6 juta ton per tahun. Produksi jagung nasional terus meningkat dari 5,3 juta ton pada tahun 1984 meningkat menjadi 11,2 juta ton pada tahun 2004 dan diperkirakan tahun 2005 mencapai 12,2 juta ton (Anonimous, 2007), pada tahun 2003 Indonesia mengimpor 1,5-2 juta ton, jumlah ini menurun menjadi 400 ribu ton akhir tahun 2005 dan diperkirakan pada tahun 2010 kebutuhan jagung nasional sekitar 21,17 juta ton.

Apriyantono (2007) mengatakan bahwa total produksi tahun 2006 mencapai 11,4 juta ton dan Sulawesi merupakan daerah prioritas pengembangan jagung nasional dengan target produksi tahun 2010 sebanyak 5 juta ton dari hamparan pertanaman seluas 1 juta hektar.

Kontribusi Sulawesi terhadap produksi jagung nasional saat ini sebanyak 12 persen dan diharapkan pada tahun 2007 Indonesia mencapai swasembada jagung. Melalui uraian tersebut dapat di lihat betapa pasar pangan sangat besar yang kita miliki dan diminati produsen pangan luar negeri, namun belum mencukupi kebutuhan pangan, pakan, dan industri nasional (Anonimous, 2007).

Produktivitas yang dicapai sekitar 3 ton/ha, sedangkan potensi produksi ditingkatkan menjadi 6-7 ton/ha jagung pipilan kering. Penggunaan jagung hibrida masih rendah, sekitar $15 \%$ dari total areal tanam 3,3 juta hektar dan potensi areal dapat dikembangkan menjadi 7,5 hektar melalui pemanfaatan lahan yang sudah terbuka (Anonimous, 2007).

Rendahnya produktivitas jagung ini disebabkan oleh penggunaan benih varietas lokal, penyiapan lahan kurang optimal, populasi tanaman terlalu tinggi atau jarak tanam kurang teratur, pemupukan kurang tepat, juga hama penyakit dan gulma belum terkendali dengan baik (Engelstad, 1985).

Pemupukan yang kurang tepat dan area penutupan tassel adalah salah satu faktor yang sangat penting dalam hubungannya dengan pertumbuhan dan produktivitas tanaman jagung (Hunter and Mortimore, 1973). Nitrogen adalah salah satu unsur hara yang di perlukan untuk pertumbuhan dan perkembangan tanaman secara optimum. Nitrogen memegang peranan penting dalam proses biokimia tanaman, yaitu sebagai penyusun enzim, klorofil, asam nukleat, dinding sel dan berbagai komponen sel (Salisbury dan Ross, 1985).

Rogi (1996) menyatakan bahwa sebagian besar petani memberikan pupuk nitrogen hanya berupa taksiran mengenai tinggi rendahnya takaran pupuk nitrogen, karena jumlah takaran pupuk yang diberikan sebenarnya terlalu kecil dibandingkan dengan nitrogen total tanah yang diperkirakan sekitar 30\% nitrogen yang diberikan hilang melalui pencucian dan denitrifikasi.

Efisiensi pemupukan nitrogen merupakan ukuran kemampuan tanaman untuk memproduksi biomassa, dimana peningkatan kandungan nitrogen tanaman berhubungan dengan rasio antara jumlah nitrogen yang diserap tanaman dengan biomassanya (Heard, 2004). Tinggi rendahnya takaran pupuk nitrogen yang diberikan sangat mempengaruhi nilai efisiensi fisiologis tanaman yang menyangkut proses anabolik dan katabolik dalam satu siklus hidup tanaman (Runtunuwu, 1990).

Manfaat yang dapat diperoleh melalui penelitian ini adalah penyusunan model dapat mensimulasi pertumbuhan dan produksi tanaman jagung melalui pemberian nitrogen dan pemangkasan tassel serta interaksi dengan lingkungan tumbuhnya dan dapat dipakai sebagai alat analisis untuk memprediksi hasil dan pengambilan keputusan.

\section{METODE PENELITIAN}

Penelitian ini dilaksanakan dalam bentuk percobaan lapang di Desa Tountimomor Kecamatan Kakas Kabupaten Minahasa. Pembuatan model di Laboratorium Modeling Tanaman Fakultas Pertanian Unsrat dan Laboratorium Modeling IPB Bogor. Uji tanah dilakukan di Laboratorium Departemen IImu Tanah dan Sumberdaya Lahan Fakultas Pertanian IPB. Penelitian ini dilaksanakan pada bulan Januari s/d 
April 2007. Bahan dan alat yang akan digunakan antara lain: benih jagung varietas hibrida jaya 1, pupuk urea, SP-36, KCL, herbisida, insektisida, plant catalyst, altimeter, termometer maksimumminimum, termometer tanah, psikrometer, penakar curah hujan, bajak traktor tangan, Leaf Area Meter. Penelitian ini menggunakan metode faktorial dua faktor yan dirancang dalam Rancangan Acak Lengkap. Faktor pertama adalah pemupukan nitrogen dengan tiga taraf yaitu: tanpa pemupukan (N0), pemupukan $46 \mathrm{~kg} \mathrm{~N} / \mathrm{ha}$ (N1), pemupukan 92 $\mathrm{kg} \mathrm{N} / \mathrm{ha}$ (N2), dan faktor kedua adalah pemangkasan tassel dengan dua taraf, yaitu tanpa pemangkasan (P0) dan pemangkasan (P1). Tiap perlakuan diulang sebanyak tiga kali. Selanjutnya dilakukan pembuatan model simulasi.

\section{Prosedur Lapang}

Persiapan tanah sebagai media tumbuh, di bajak dengan menggunakan traktor tangan di sisir dua kali dengan tujuan menggemburkan tanah dan untuk memisahkan dari batu-batuan dan sampah organik lainnya. Petak percobaan di buat ukuran 8 $\mathrm{x} 3 \mathrm{~m}$. Benih ditanam dengan lubang tugal $3 \mathrm{~cm}$ tiap lubang tanam berisikan 1 benih. Jarak tanam $70 \mathrm{x}$ $20 \mathrm{~cm}$ dan kedalaman benih 4-5 cm. Pengairan dilaksanakan sesuai kebutuhan tanaman, minimal 6 kali pengairan selama pertumbuhannya terutama pada saat pembungaan dan pengisian biji. Pemupukan nitrogen diberikan sebanyak tiga kali yaitu pada saat tanam, 30 hari setelah tanam dan 40 hari setelah tanam, dilanjutkan dengan penyemprotan Plant Catalyst konsentrasi 0,25\% setara dengan $2,5 \mathrm{gr} / \mathrm{l}$ untuk mengoptimalkan serapan hara makro dan mikro yang di butuhkan tanaman. Jarak lubang pemupukan dengan tanaman $5 \mathrm{~cm}$. Fosfor dan kalium sebagai pupuk dasar diberikan hanya satu kali pada saat tanam, dengan takaran $150 \mathrm{~kg} \mathrm{SP-36}$ dan $75 \mathrm{~kg} \mathrm{KCl} / \mathrm{ha}$. Sampel tanah diambil pada kedalaman $20-30 \mathrm{~cm}$ dengan menggunakan bor tanah.

Pemangkasan tassel dilakukan 14 hari setelah penyerbukan, saat munculnya rambut bunga betina. Pengamatan dilakukan pada setiap fase pertumbuhan dan perkembangan tanaman. Sampel bobot kering tanaman diambil setiap 14 hari untuk analisis tumbuh tanaman. Panen dilaksanakan saat tampilan rambut pada tongkol telah mengering.

\section{Prosedur Kerja Penyusunan Model}

Model simulasi yang dikembangkan (Handoko, 1996) bahwa berdasarkan tanggapan pertumbuhan tanaman terhadap nitrogen serta interaksinya. Prosedur penyusunan model meliputi: Formula Perhitungan Biomassa. Produksi biomassa potensial harian di hitung berdasarkan efisiensi penggunaan radiasi surya yang diintersepsi tajuk tanaman, hubungannya di berikan oleh Hukum Beer yaitu :

\section{I = Qo (Qi- $\sigma) ; \sigma=e^{-k ~ I L D ~}$}

Dimana:

Qo = Radiasi yang tiba di atas tajuk tanaman $\left(\mathrm{MJm}^{2}\right)$

I = intensitas berkas cahaya

e = kapasitas benda memancarkan atau menyerap radiasi. (e daun $=0,95$ )

$\mathrm{Qi}=$ Radiasi yang diserap $\left(\mathrm{MJm}^{2}\right)$

$\sigma=$ Proporsi radiasi surya yang ditransmisikan oleh tajuk tanaman

$\mathrm{k}=$ Koefisien pemadaman

\section{ILD = Indeks Luas Daun}

Produksi biomassa potensial dihitung berdasarkan hasil kali antara efisiensi penggunaan radiasi surya $(\varepsilon)$ dengan radiasi intersepsi (Qi). Nilai efisiensi penggunaan radiasi di tentukan sebesar $\varepsilon$ $=0.0014 \mathrm{~kg} \mathrm{MJ}^{-1}$

\section{$B b=\varepsilon Q i=\varepsilon\left(1-e^{-k}\right.$ ILD $) Q_{0}$}

Dimana:

$\mathrm{Bb}=$ Produksi biomassa potensial $\left(\mathrm{kg} \mathrm{ha}^{-1} \mathrm{~d}^{-1}\right)$

$\mathrm{E}=$ efisiensi penggunaan radiasi $\left(\mathrm{kg} \mathrm{MJ}^{-1}\right)$.

Produksi biomassa potensial tersebut menganggap ketersediaan air bukan merupakan faktor pembatas. Produksi biomassa aktual dihitung dengan mempertimbangkan ketersediaan air, yang dihitung berdasarkan nisbah antara hantaran stomata aktual (фa) dengan nilai hantaran stomata maksimumnya (фpm). Berikut adalah perhitungan faktor ketersediaan air (fw) dan produksi biomassa aktual (Ba).

$\mathrm{Fw}=\phi p a / \phi p$

$B a=f w \cdot B b$

Ba dalam $\mathrm{kg}$ ha1 $\mathrm{d}^{1}$. Hantaran stomata aktual (фpa, mm s-1) dihitung dari transpirasi harian. Transpirasi aktual dihitung dari sub model air dan 
defisit tekanan uap air. Hantaran stomata maksimum ( radiasi surya bersih (Qsn).

$\phi \mathrm{m}=0.5+0.020 \mathrm{Qsn}$

Dimana: Qsn dalam (Wm²).

Kehilangan bahan kering dari organ vegetatif (daun, batang dan akar) selama pemunculan kecambah sampai pembuangan melalui proses respirasi pertumbuhan $\left(R_{g}\right)$ dan respirasi pemeliharaan $\left(R_{m}\right)$ yang dihitung berdasarkan suhu udara dan massa masing-masing organ. Pertumbuhan masing-masing organ tanaman dan yang hilang melalui respirasi sebagai berikut :

\section{$\mathrm{dW}_{\mathrm{x}}=\eta_{\mathrm{x}} B_{\mathrm{a}} \cdot R_{\mathrm{g}} R_{\mathrm{m}} \eta_{\mathrm{x}}\left(1-\mathrm{K}_{\mathrm{g}}\right) B_{\mathrm{a}}-\mathrm{K}_{\mathrm{m}} \mathrm{W}_{\mathrm{x}} Q_{10}$}

Dimana:

$Q_{10}=2^{(T-20) / 10}$

$\mathrm{dW}_{\mathrm{x}}=$ penambahan massa organ $\mathrm{x}\left(\mathrm{kg} \mathrm{ha}^{-1} \mathrm{~d}^{-1}\right)$

$\mathrm{Rm}=$ respirasi pemeliharaan $\left(\mathrm{kg} \mathrm{ha}^{-1} \mathrm{~d}^{-1}\right)$

$\eta_{x}=$ proporsi biomassa yang dialokasikan ke organ $x$ (daun, batang akar dan biji)

$\mathrm{k}_{\mathrm{m}}=$ koefisien respirasi pemeliharaan

$\mathrm{k}_{\mathrm{g}}=$ koefisien respirasi pertumbuhan

$\mathrm{W}_{\mathrm{x}}=$ massa organ $\mathrm{x}\left(\mathrm{kg} \mathrm{ha}^{-1}\right)$

Tahap fenologi adalah faktor yang mempengaruhi pembagian asimilat pada organorgan vegetatif (daun, batang dan akar) selama kecambah muncul sampai pembungaan. Pada awal pertumbuhan, produksi biomassa hanya dialokasikan ke daun, batang dan akar dengan alokasi terbanyak pada daun. Sampai pembungaan. Alokasi biomassa ke daun dan akar berkurang sedangkan alokasi ke batang bertambah dengan fase perkembangan tanaman. setelah fase pembungaan, seluruh produksi biomassa dialokasikan ke biji. Berikut adalah parameter yang di gunakan untuk menghitung alokasi biomassa ke masing-masing organ.

\section{Indeks Luas Daun (ILD)}

ILD dihitung sebagai fungsi laju pertumbuhan daun harian (dw1) dan konsentrasi nitrogen daun. Persamaan indeks luas daun dapat dihitung dengan persamaan berikut :

DILD $=\{[$ Nact 1$] \mathrm{dw} 1 / 20\} 10^{2}, \mathrm{dw} 1>0$

$=\left\{\left[\mathrm{Nact}_{1} \mathrm{dw} 1 / \mathrm{s} \ln \right\} 10^{2}, \mathrm{dw}_{1} \leq 0\right.$

Dimana: $\mathrm{dw}_{1}=$ pertumbuhan daun $\left(\mathrm{kg} \mathrm{ha}^{-1} \mathrm{~d}^{-1}\right)$

Nact $_{1}=$ konsentrasi nitrogen daun $(\%)$

$\sin \quad=$ nitrogen daun spesifik

\section{Pengambilan Nitrogen}

Akar mengambil nitrogen awalnya dari lapisan permukaan dan kemudian pada lapisan terbawah didalam zona perakaran sampai kebutuhan tanaman terpenuhi.

Pada masing-masing lapisan, pengambilan nitrogen dilakukan dengan aliran massa dan pengambilan aktif. Aliran massa dihitung sebagai hasil dari aliran air ke akar $\{\operatorname{Tr}(1)\}$ dan konsentrasi nitrogen tanah dan nitrat $\left\{\mathrm{NO}_{3 c}(1)\right\}$.

$\operatorname{Nup}_{m}(1)=T_{r}(1) \mathrm{NO}_{3 c}(1)$

semua lapisan 1, $\mathrm{NO}_{3 \mathrm{c}}(1) \mathrm{di}$ hitung dari rasio nitrogen tersedia $\left\{\mathrm{NO}_{3}(1)\right\}$ dan kadar air (1).

$\mathrm{NO}_{3 c}(1)=\mathrm{NO}_{3}(1) / \phi(1)$

Pengambilan aktif dihitung dengan persamaan Michaelis-Menten

$\operatorname{Nup}_{\mathrm{at}}(1)=\mathrm{W}_{\mathrm{r}}(1) \mathrm{t}_{\mathrm{n}} \mathrm{NO}_{3 \mathrm{c}}(1) /\left[\mathrm{k}_{\mathrm{m}}+\mathrm{NO}_{3 \mathrm{c}}(1)\right]$

Dimana:

$\mathrm{W}_{\mathrm{r}}(1)=$ bobot akar di dalam lapisan $1\left(\mathrm{~kg} \mathrm{ha}^{-1}\right)$

$t_{n} \quad=$ pengambilan nitrogen per unit bobot kering $\operatorname{akar}\left(\mathrm{kg} \mathrm{N} \mathrm{kg}^{-1} \mathrm{~d}^{-1}\right)$

$\mathrm{km}=\operatorname{konsentrasi} 1 / 2$ jenuh $\left(\mathrm{kg} \mathrm{N} \mathrm{ha}^{-1} \mathrm{~mm}^{-1}\right)$

\section{Mobilisasi Dan Pembagian Nitrogen}

Daun dan batang memiliki nitrogen struktural dan labil. Selama pelayuan nitrogen labil dimobilisasi antara organ-organ, sementara nitrogen struktural di dalam jaringan-jaringan yang mati. Pelayuan dari daun dan batang memobilisasi nitrogen ( $\mathrm{dN}_{\text {moby }}$ ) sebagai hasil dari laju pelayuan $\left(D_{\gamma}\right)$ dan konsentrasi nitrogen [Nact $\left.\mathrm{N}_{\gamma}\right)$ di atas suatu konsentrasi minimum $\left(\mathrm{N}_{\mathrm{mim}}\right)$ ditulis sebagai :

$\mathrm{dN}_{\text {moby }} \mathrm{D}_{\gamma}\left[\mathrm{Nact}_{\gamma}\right]-\left[\mathrm{N}_{\mathrm{mln}}\right] \mathbf{1 0}^{-2}$

Selama pengisian biji, nitrogen di mobilisasi dari daun ke batang. Kebutuhan nitrogen dipengaruhi oleh bobot biji $(\mathrm{Wg})$, konsentrasi nitrogen actual [Nactg] dan konsentrasi maksimum.

$\left[\mathrm{N}_{\max g}\right]=3 \%$, yang di tulis sebagai : 
$\mathrm{Ndem}_{g}=\mathrm{Wg}\left\{3-\left[\mathrm{Nact}_{g}\right]\right\} 1^{-2}$

\section{Nitrogen Tanah}

Laju ammonifikasi pada masing-masing lapisan dihitung sebagai fungsi dari nitrogen organik, kadar air tanah dan temperatur $\left(Q_{10}=2^{(T-10) / 20}\right)$ yang mengikuti persamaan :

$\mathrm{dNH} 4(1)=Q_{10} k_{a m} o_{n}(1) \theta(1) \geq \theta_{\text {wp }}(1)=\theta, \theta(1)<$ $\theta_{\text {wp }}(1)$.

Dimana:

$o_{n}=$ nitrogen organik di dalam lapisan $(\mathrm{kg}$ ha-1).

$k_{a m}=$ laju konstan, yang memiliki nilai $9610^{-6} \mathrm{~d}^{-1}$ (Rogi, 1996).

Semua lapisan laju nitrifikasi potensial $\left(\mathrm{dNO}_{3 p}(1)\right)$ tergantung dari tersedianya $\mathrm{NH}_{4}\{\mathrm{NH} 4(1)\}$.

$\mathrm{dNO}_{3 \mathrm{P}}(1)=\mathrm{k}_{\mathrm{nlt}} \mathrm{NH}_{4}(1)$

Dimana:

$\mathrm{K}_{\text {nitt }}=$ konstanta laju nitrifikasi $\left(0,05 \mathrm{~d}^{-1}\right)$

Lamanya transformasi $\mathrm{NH}_{4}$ Ke $\mathrm{NO}_{3}$ antara 14-19 hari, tergantung dari tipe dan kedalaman tanah.

Laju nitifikasi aktual $\left\{\mathrm{dNO}_{3 a}(1)\right\}$ dipengaruhi kelengasan tanah $\{\mathrm{fe}(1)\}$, temperatur (Q10) dan $\mathrm{pH}$ $\{\mathrm{fpH}(1)\}$, persamaannya adalah sebagai berikut :

$d N_{3 a}(1)=Q_{10} d N_{3 p}(1) \max \left\{f_{\theta}(1), F_{p H}(1)\right\}$,

Dimana:

$f_{\theta}(1)=0,038+1,02 \theta(1) / \theta_{\mathrm{rc}}(1)$

$f_{p H}(1)=$ laju nitrifikasi relatif $(0-1)$ di dalam $p H$ mempunyai rentang 5-8.

\section{Pencucian (Leaching)}

Pelepasan nitrogen dari masing-masing lapisan $\left(\mathrm{L}_{\mathrm{NO} O}(1)\right)$ dengan air yang di perkolasi $(\mathrm{Pc}(1)$ yang ditulis sebagai :

$\left(\mathrm{L}_{\mathrm{NO} 3}(1)\right)=\mathrm{Pc}(1) \mathrm{NO}_{3}(1) / \phi_{\mathrm{rc}}(1)+\mathrm{Pc}(1)$

\section{HASIL DAN PEMBAHASAN}

Tampilan model menunjukkan bahwa selama periode pertumbuhan tanaman terjadi kenaikan biomassa total tanaman yaitu $8000 \mathrm{~kg} / \mathrm{ha}$ kenaikan biomassa total diindikasikan adanya sinergitas antara seluruh organ tanaman yaitu akar, batang, daun dan biji terhadap kondisi agroklimat zona pertumbuhan tanaman jagung. Produksi biomassa tanaman tergantung pada ukuran organ tanaman yang berfotosintesis (Thorne dan Thorne,1979). Input pada penelitian ini adalah pemberian nitrogen yang tepat berperan pada pertumbuhan vegetatif tanaman yang menyebabkan peningkatan indeks luas daun (Paruntu dan Palenewen, 1990). Dengan demikian proses asimilasi berlangsung lebih lama dan biomassa yang terbentuk akan lebih banyak selama periode fotosintetis (Jones, 1983). Respon simulasi model kadar nitrogen dimulai sejak 4 hst dengan kadar nitrogen lebih kecil dari $0,2 \%$.

Model memperlihatkan kecenderungan peningkatan nitrogen daun hingga kadar 1,6\% pada umur tanam 49 hst. Hal ini menggambarkan periode penyerapan nitrogen yang sangat tinggi pada fase vegetatif, untuk memenuhi kebutuhan nitrogen pada pembentukan makromolekul protein. Tampilan model menunjukkan bahwa selama periode pertumbuhan tanaman terjadi kenaikan biomassa total tanaman yaitu $8000 \mathrm{~kg} / \mathrm{ha}$ kenaikan biomassa total diindikasikan adanya sinergitas antara seluruh organ tanaman yaitu akar, batang, daun dan biji terhadap kondisi agroklimat zona pertumbuhan tanaman jagung. Produksi biomassa tanaman tergantung pada ukuran organ tanaman yang berfotosintesis (Thorne and Thorne,1979). Input pada penelitian ini adalah pemberian nitrogen yang tepat berperan pada pertumbuhan vegetatif tanaman yang menyebabkan peningkatan indeks luas daun (Paruntu dan Palenewen, 1990).

Dengan demikian proses asimilasi berlangsung lebih lama dan biomassa yang terbentuk akan lebih banyak selama periode fotosintetis (Jones, 1983). Respon simulasi model kadar nitrogen dimulai sejak 4 hst dengan kadar nitrogen lebih kecil dari $0,2 \%$. Model memperlihatkan kecenderungan peningkatan nitrogen daun hingga kadar $1,6 \%$ pada umur tanam 49 hst. Hal ini menggambarkan periode pe nyerapan nitrogen yang sangat tinggi pada fase vegetatif, untuk memenuhi kebutuhan nitrogen pada pembentukan makro molekul protein. Pertumbuhan linier berhubungan dengan penurunan internal dari konsentrasi nitrogen, dan ketika bobot tanaman me ningkat maka laju pertumbuhan per unit nitrogen 
akan menurun yang disebabkan oleh efek penuaan dan shading internal (Handoko 1996). Daun memiliki struktur nitrogen yang labil. Selama penuaan nitrogen labil dimobilisasi antara organorgan (Thorne, 1979). Akumulasi nitrogen diawal pertumbuhan relatif lambat, tetapi setelah tanaman berumur 28 hari setelah tanam akumulasi nitrogen dan sangat cepat.

Resistensi terhadap pergerakan air dalam tanaman dan dalam tanah, maka tanaman tidak dapat mengabsorbsi air secepat kehilangan air yang meningkat pada siang hari, karena potensial air daun mencapai titik terendah. Walalangi (1988) menyatakan bahwa fluktuasi potensial air daun yang terjadi dalam siklus satu hari mempengaruhi pertumbuhan khususnya pemanjangan daun jagung. Pembesaran daun merupakan parameter fisiologis yang pertama di pengaruhi bila tanaman mengalami stress air, hal ini disebabkan tekanan turgor dalam sel yang diperlukan untuk pembesaran sel dipengaruhi oleh potensial air. Laju pemanjangan daun Jagung menurun secara linier dengan turunnya potensial air daun dan mencapai nol pada potensial air daun -7,0 bar (Walalangi, 2007). Respon simulasi model kadar nitrogen dimulai sejak empat hst dengan kadar nitrogen lebih kecil dari $0,2 \%$. Model memperlihatkan kecenderungan peningkatan nitrogen daun hingga kadar 1,6\% pada umur tanam 49 hst menggambarkan periode penyerapan nitrogen yang sangat tinggi disebutkan pada fase vegetatif kebutuhan nitrogen untuk pembentukan makromolekul protein. Pertumbuhan linier berhubungan dengan penurunan internal dari konsentrasi nitrogen, dan ketika bobot tanaman meningkat maka laju pertumbuhan per unit nitrogen akan menurun yang disebabkan oleh efekpenuaan dan shading internal (Handoko, 1996). Daun memiliki struktur nitrogen yang labil. Selama penuaan nitrogen labil dimobilisasi antara organorgan dan akumulasi nitrogen awal pertumbuhan relatif lambat, tetapi setelah tanaman berumur 28 hari setelah tanam akumulasi nitrogen dan sangat cepat (Rogi (2002).

Hubungannya dengan faktor ketersediaan air, Walalangi (2007) menyatakan bahwa resistensi terhadap pergerakan air dalam tanaman dan dalam tanah telah tertentu, maka tanaman tidak dapat mengabsorbsi air secepat kehilangan air yang meningkat pada siang hari, karena potensial air daun mencapai titik terendah.

\section{Biomassa Total}

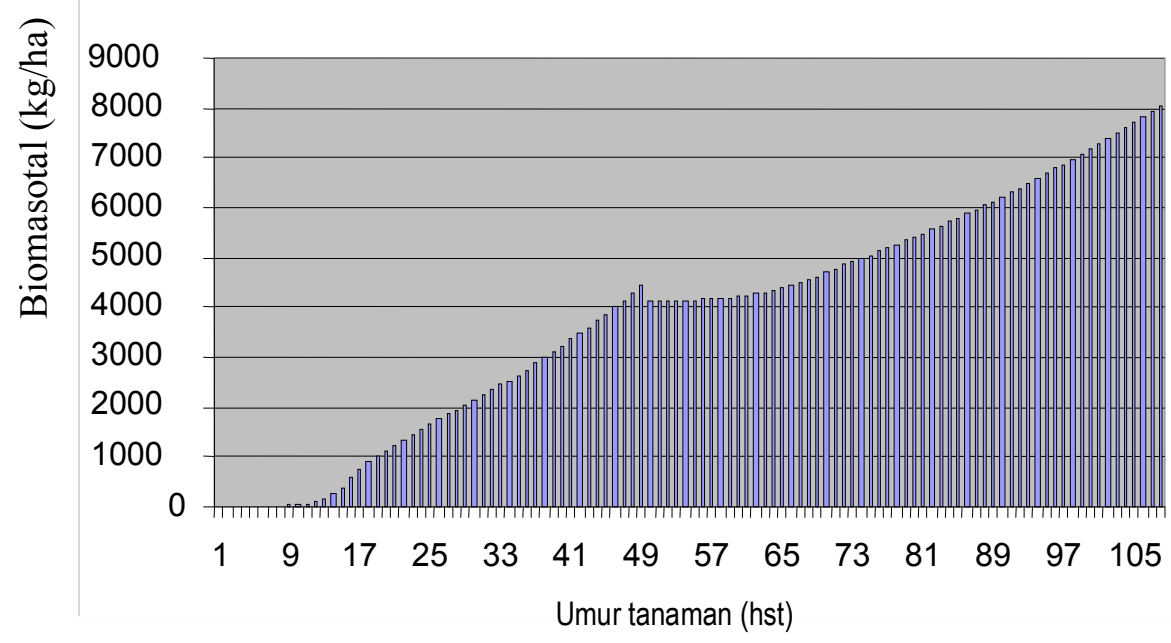

Gambar 1. Tampilan model simulasi biomassa total akar, batang, daun dan biji ( Simulation models display th total biomass of roots, steem, leaves and seeds) 


\section{Nitrogen Daun}

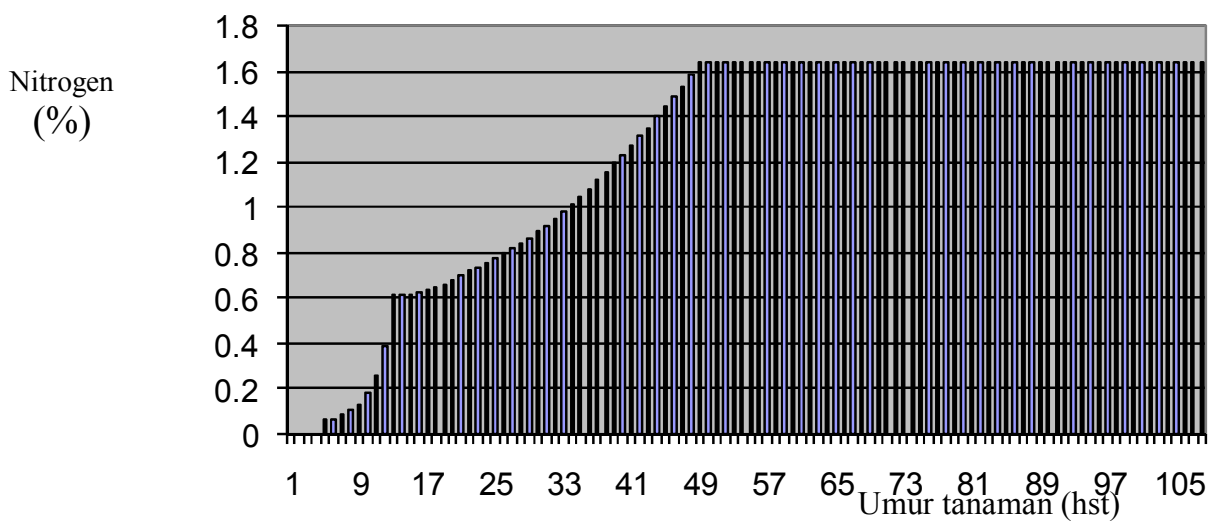

Gambar 2. Tampilan model simulasi kadar nitrogen daun (Views leaf nitrogen simulation model)

\section{Biomassa Tassel}

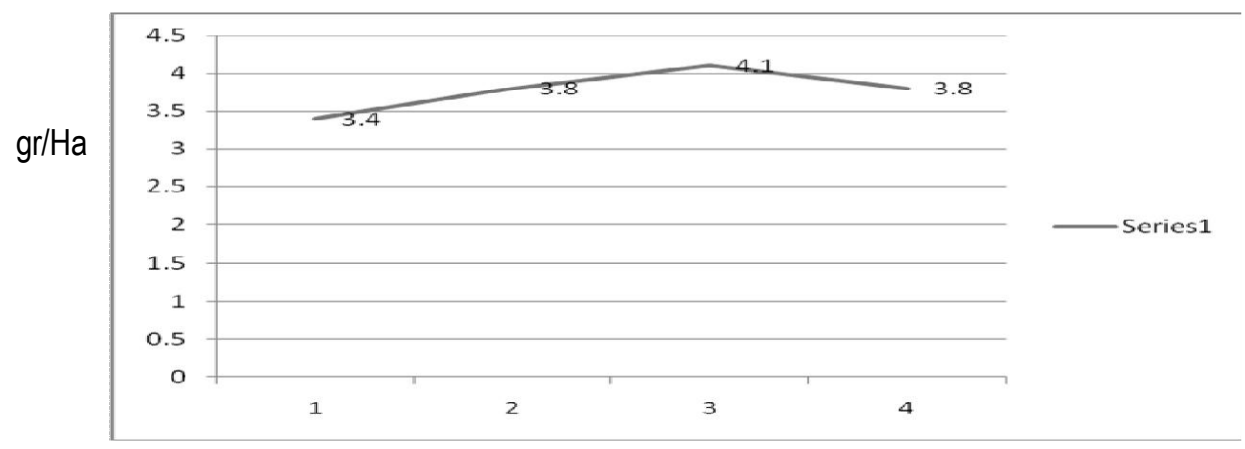

Gambar 3. Tampilan Model Simulasi Akumulasi biomassa tassel ( View of simulation model tassel biomass accumulation)

Fluktuasi potensial air daun yang terjadi dalam siklus satu hari mempengaruhi pertumbuhan khususnya pemanjangan daun jagung. Pembesaran daun merupakan parameter fisiologis yang pertama dipengaruhi bila tanaman mengalami stress air, hal ini di sebabkan tekanan turgor dalam sel yang diperlukan untuk pembesaran sel di pengaruhi oleh potensial air. Laju pemanjangan daun jagung menurun secara linier dengan turunnya potensial air daun, dan mencapai nol pada potensial air daun $-7,0$ bar (Walalangi, 2007). Nitrogen merupakan bahan pembentuk utama protein, protoplasma, pigmen klorofil, komponen ATP dan pembawa energi respirasi berjuang dalam pembentukan sel tanaman berupa kalsium, pektat, selulosa dan lignin. Proporsi pembagian nitrogen yang di serap daun berdasarkan pelacakan isotop menunjukkan bahwa nitrogen lebih banyak dialokasikan ke daun (Rogi, 2002). Pengamatan lapangan periode ke 2 menunjukkan biomassa tassel $3.8 \mathrm{gr} / \mathrm{ha}$, pada pengamatan ke 3 menunjukkan adanya kenaikkan berat tassel hingga $4.1 \mathrm{gr} / \mathrm{ha}$.

Kenaikkan ini disebabkan proses metabolisme masih terjadi translokasi fotosintat untuk pemenuhan energi pertumbuhan dan perkembangan sel-sel. Pada pengamatan ke 4 terjadi fluktuasi penurunan hingga $3,8 \mathrm{gr} / \mathrm{ha}$. Hal ini diduga pada proses metabolisme tanaman, hasil asimilat ditranslokasikan berdasarkan kebutuhan organorgan tanaman serta pengaruh lingkungan tanaman.

Hasil penelitian lapangan biomassa tassel yang dimodelkan menunjukkan penurunan total 
dari pada biomassa tassel akibat adanya perlakuan pemangkasan (Wilhelm and Schepers,1995). Penurunan ini diduga adanya bentuk adaptasi tanaman terhadap pelukaan akibat pemangkasan. Asimilat yang disimpan dalam bentuk biji dan biomassa, sebagian digunakan untuk perbaikan luka tanaman melalui pembentukan sel-sel baru (Weingartner, 2002). Esensi pemangkasan tassel hanya mengurangi efek naungan pada daun-daun tanaman jagung dan berdampak pada kenaikan produktivitas biomassa, melalui fotosintesis dan asimilasi bersih. Weingartner (2002) menyatakan bahwa porsi terbesar kenaikan biomassa ketika intersepsi cahaya ke tanaman bukan menjadi faktor pembatas melalui perlakuan pemangkasan tassel. Pemangkasan tassel hanya meningkatkan perubahan karakter biji tanaman jagung (Hunter and mortimore, 1973).

Populasi tanaman jagung dalam keadaan stress lingkungan, misalnya kesuburan tanah rendah, atau kekeringan, kenaikan biomassa dapat di tingkatkan melalui pemangkasan tassel. Pengaruh tassel terhadap produksi yaitu pada waktu terjadi fertilisasi yaitu semakin banyak jumlah polen yang di produksi kemungkinan akan meningkatkan fertilisasi yang berdampak pada total produksi biomassa biji (Weingartner,2002).

\section{KESIMPULAN DAN SARAN}

Berdasarkan hasil penelitian yang dilakukan dapat disimpulkan sebagai berikut: Model mampu mensimulasi pertumbuhan danproduksi tanaman jagung dengan biomassa total8000 kg/ha. Model mampu mensimulasi nitrogen daun optimum tertinggi dilevel $1,6 \%$ pada 49 hari setelah tanam Biomassa tassel tertinggi hasil pengukuran lapang dihasilkan pada perlakuan pemangkasan (P1) yaitu, $4 \mathrm{gr} / \mathrm{ha}$.

\section{DAFTAR PUSTAKA}

Anonimous, 2007. Notulen Rapat Dewan Jagung Nasional. Jakarta (http.//www.produksi jagung/djn.htm) 2007. Produksi Jagung Meningkat Kurun Waktu Lima Tahun Terakhir. Warta
Puslitbang. http://www.produksijagung/ index. htm)

Apriyantono, 2007. Seminar dan Ekspose Inovasi Teknologi Jagung Mendukung Revitalisasi Pertanian. Makassar. Puslitbang. (http.//www produksijagung/index.php.htm.) Engelstad, O. P. 1985. Fertilizer Technology And Use.Third Edition. Soil Science Society Of America, Inc.

Handoko, 1996 Analisis Sistem dan Model Simulasi Komputer untuk Perencanaan Pertanian di Indonesia. IPB- Bogor.

Hunter, J and L. Mortimore, 1973. Yield Changes Of 10 Inbreds Following Tassel And Leaf Removal. CSIRO Publishing. (http://www./ maize. tasseleffect. htm)

Heard, J. 2004. Nutrient Uptake And Removal Patterns In High Yielding Manitoba Corn Manitoba Agriculture. (http://www.maize. corncob.htm).

Jones, H. G. 1983. Plants And Microclimate. A quantitative approach to environmental plant physiology. Cambridge University Press. $323 p$.

Milthorpe, F.L and J.Moorby. 2001. An Introdution To Crop Physiology. Melbourne

Paruntu, J, dan J. L. Palenewen. 1990. Analisis Tumbuh Dan Efisiensi Penggunaan Radiasi Pada Tanaman Jagung. Fakultas Pertanian Unsrat. Manado. 25p.

Runtunuwu, D. S. 1990. Tumpangsari Jagung dan Kedelai Di Bawah Naungan Kelapa Tua. Tesis Magister. KPK IPB-UNSRAT. Manado.

Rogi, J. E. X. 1996. Penyusunan Model Simulasi Dinamika Nitrogen Pertanaman Kelapa Sawit (Elaeis guineensis Jacq.) Di Unit Usaha Bekrie Provinsi Lampung. Disertasi Doktoral. IPB. Bogor

Salisbury, F.B \& C.W Ross. 1985. Plant Physiology. Wardsworth Publ.Co. California.

Thorne, D. W. dan M. D. Thorne. 1979. Soil, Water, and Crop Production. The Avi Publishing Company, Inc. Connecticut. USA. 353pp

Walalangi, I. Th. 1988. Pengaruh Stres Air Dan Pemupukan Nitrogen Terhadap Pertumbuhan Jagung (Zea mays L.) Tesis Magister. Fakultas Pascasarjana. Institut Pertanian Bogor.

Th. 1996. Pengaruh Stress Air \& Pemupukan Nitrogen Terhadap Pertumbuh- 
an dan Hasil tanaman Jagung (Zea Mays L). Eugenia (2) 1: 1-7.

. Th. 2007. Pemupukan Nitrogen dan Ketahanan Jagung Terhadap Kekeringan. Pidato Pengukuhan Guru Besar Tetap IImu Fisiologi Tumbuhan Fakultas Pertanian Unsrat.

Wilhelm, S. and R. Schepers, 1995. The effect Of Leaf Removal During Detasseling On Yield
And Yield Components In the Inbred. (http://maize. Detassel ing.htm)

Weingartner, U. 2002. Combined effect Of Male Sterility And Xenia On Grain Yield And Yield Components In Maize (Zea mays L.). Ph.D Disertasi. Swiss Federal Institute Of Technology Zurich. 